\title{
Cooperation Between Learning Venues and its Limits: The Hotel Industry in Cancún (Mexico)
}

\author{
Beke Vogelsang ${ }^{1}$, Natascha Röhrer ${ }^{2}$, Martina Fuchs ${ }^{2}$, Matthias Pilz ${ }^{\star 1}$ \\ ${ }^{1}$ Chair of Economics and Business Education, University of Cologne, Herbert-Lewin-Str. 2, \\ 50931 Cologne, Germany \\ ${ }^{2}$ Department of Economic and Social Geography, University of Cologne, \\ Meister-Ekkehart-Str. 9, 50937 Cologne, Germany
}

Received: 27 November 2020, Accepted: 07 September 2021

\begin{abstract}
Purpose: Recently, high-quality vocational education and training has attracted much attention in Mexico. In this context, more practically applied skills are taught "on a dual basis", combining classroom-based training with practical, on the job, training within the company. Dual practices are expected to modernize the skill formation system, and simultaneously support companies, while ensuring provision of skilled workers. For this reason, the Mexican vocational training system has been reformed in recent years. Hence, it is necessary for vocational schools and universities interact closely with companies in order to coordinate their activities. The aim of this paper is to examine the cooperation between learning venues of vocational education in the hotel industry in Cancún (Quintana Roo, Mexico), one of the most important tourism destinations in Latin America. By using this empirical case, the study contributes to research in vocational education and training about the principles that are necessary for successful cooperation between learning venues. This study thereby critically discusses the setting of common goals, communication between companies and training organizations, and governance.
\end{abstract}

Method: In an exploratory approach and based on a qualitative framework, ten face-to-face expert and semi-structured interviews were conducted in Cancún. The interviews were then fully transcribed and evaluated using qualitative methods. The exploratory and qualitative study is complemented by further document analysis.

*Corresponding author: matthias.pilz@uni-koeln.de

ISSN: $2197-8646$

https://www.ijrvet.net

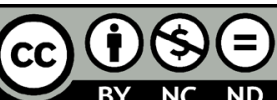


Findings: The results show that for successful cooperation between learning venues, the coordination of a common goal (to secure the availability of skilled workers) between different actors, and communication between companies and educational organizations (vocational school/university), are particularly important for successful cooperation. Furthermore, it seems that companies are taking on a dominant role, so that vocational training organizations must be more in line with the wishes of the hotels. The results indicate that partnership-based action is not very obvious. Accordingly, the aspect of governance plays a subordinate role regarding the cooperation between hotels and educational organizations.

Conclusion: There are general findings, which can also be useful for other regions. This study shows that learning venues cooperation are possible with both vocational schools and universities. In order for learning venues cooperation to be successful, certain principles are needed. However, these principles are related to the specificity of a region or a particular industry.

Keywords: Tourism, Hotel Industry, Cooperation Between Learning Venues, Limits, Mexico, VET, Vocational Education and Training

\section{Introduction}

Tourism is very important in the economy of many regions in Latin America, and it is growing constantly there (López, 2020a). In 2018, Mexico generated around 22.5 billion U.S. dollars due to international tourists alone (López, 2020b). The relevance of the sector is also evident from the gross domestic product (GDP), 8.5\% of GDP is generated by tourism (OECD, 2017).

In recent years, the tourism sector in Mexico has provided employment for more and more people, and at the beginning of 2020 the number of people employed in tourism was approx. 4.5 million. About $9 \%$ of all employees in Mexico work in the tourism industry (SEDETUR \& INEGI, 2020). Because of its relevance to the country, the promotion of tourism is considered a priority of the Mexican government.

In order to further expand this sector, not only a corresponding tourism infrastructure is needed, but also a well-trained workforce (e.g. Brown et al., 2001; ILO, 2011; OECD, 2018). Especially the tourism sector needs skilled workers at the intermediate level; thus, the importance of vocational training is coming into sharper focus (Baum, 2002; Budría \& TelhadoPereira, 2009).

The efforts being undertaken in this regard in Mexico are a good example. The Mexican government reformed the national vocational training system in the 2010s, and introduced a Mexican model of dual training (Modelo Mexicano de Formación Dual, MMFD), to impart practical work experience. For this purpose, the combination of classroom-based and workplace-based training is important. During this reform process, the involved actors also 
developed training concepts for the tourism sector (BIBB, 2015; CAMEXA, n.d). In the literature about different training modes, the design and interaction of the two learning venues is repeatedly presented as particularly successful in combining theory and practice in the learning process (Fürstenau et al., 2014). Very often, the dual apprenticeship system in the German speaking countries is regarded as a role model for a fruitful combination of the different learning venues (Barabasch \& Heller, 2020; BMBF, 2013; Lassnigg, 2017; Smith, 2019). However, cooperation between learning venues is only one aspect of the German dual system (e.g. Gonon, 2013; Pilz \& Fürstenau, 2019; Raggatt, 1988).

The study presented here takes up the focus of vocational training research, and examines exclusively the cooperation between learning venues, since this is also one important goal for MMFD in Mexico: "Implementation and improvement of dual vocational education and training in schools and Business" (BIBB, n.d.). Since German actors are involved in the implementation and consolidation of MMFD, and the German dual system is considered a model for MMFD (BIBB, n.d; Wiemann \& Fuchs, 2018), the German concept of cooperation between learning venues will be presented (see section 2.1). Nevertheless, the concept of vocational education is still further developed and continues to be modified.

The emphasis of the study is on the principles which positively influence the cooperation between the different learning venues. Callan and Ashworth (2004) write for instance: "Open and regular communication is central to successful training partnerships" (p. 52). Important principles are already being discussed not only in various disciplines, but also specifically for the tourism industry (e.g. Augustyn \& Knowles, 2000). Therefore, even cooperation between learning venues seems to need certain principles to be successful. Previous international research, however, shows that cooperation between learning venues is often not realized, or is difficult to arrange and maintain (Pilz \& Wiemann, 2021). Reasons cited from a company's point of view include inadequate quality (for example of teacher's education or technical equipment in the vocational schools) or inadequate standardization of curricula (Pilz, 2016; Pilz, 2017).

After all, the tourism sector in Mexico has not yet been researched from a training perspective. Therefore, part of this investigation will be to examine the principles which are particularly important for cooperation between learning venues, thereby focusing on the tourism sector in one important region for tourism in Mexico (Cancún).

The focus of this study on Cancún is due to the region's growing importance for the Mexican economy in recent decades (OECD, 2017). Until the 1960s, Cancún was still characterized by a peripheral rural appearance (Carte et al., 2010; Torres \& Momsen, 2005a), which changed fundamentally with the initiation of the Mexican government's master plan for tourism development (Torres \& Momsen, 2005b). Since then, the city of Cancún has been steadily expanded, with an associated hotel zone located along a lagoon about $20 \mathrm{~km}$ long. In the meantime, the number of hotels has risen to around 1,000, and over six million tourists 
visit the region every year (SEDETUR, 2019; Statista, 2020). The region around Cancún has developed as one of the most important international tourist destinations of Latin America in just under 40 years (Statista, 2018). This development is also due to state support and promotion (Brenner \& Aguilar, 2002; Torres \& Momsen, 2005a).

The tourism boom has attracted many workers from other parts of the Yucatán Peninsula, which is strongly influenced by the Maya population, and workers from other areas of Mexico. As a booming tourist destination, Cancún therefore is characterized by many young (interregional) immigrants, who sometimes are regarded as socially uprooted (Reyes Miranda \& Cazal Ferreira, 2009). In addition, some studies criticize that the increase in economic growth has only limited effects on the social welfare of the region (Torres \& Momsen, 2005b), since only few employers have offered regular employment contracts with better pay in the past, and the vast majority of jobs are on temporary low-wage contracts (Bianet Castellanos, 2010). As a result, the local hotel industry lacks semi-skilled employees, such as receptionists, advanced housekeeping and service personnel, who are used for demanding and complex tasks. Therefore, the provision of vocational training, especially in terms of cooperation between learning venues, could be an opportunity for enterprises to obtain sufficiently trained personnel.

In the following, the state of research concerning the cooperation between learning venues and the principles necessary for successful cooperation is presented. After an explanation of the methodology used, the two actors and their cooperation are discussed with reference to the establishment of dual practices. The following also explains the point of view of the interview partners about the key principle of successful cooperation. Afterwards, the findings will be assigned to the principles and then discussed.

\section{Learning Venues and Principles of Successful Cooperation in the Literature}

\subsection{Cooperation Between Learning Venues}

As discussed in the introduction, the combination of classroom-based and workplace-based training has recently started to spread in Mexico, and the German dual system serves as role model for the Mexican actors. In this study, the German dual system will be used and critically discussed as a reference to detect and define cooperation between learning venues. For this reason, it is important for readers who are not familiar with the German dual system, that the concept "cooperation between learning venues" be briefly described. 
The terms learning venues or locations of learning (in German language called "Lernort") have gained popularity to describe learning at two places (company/school) in Germany (Deissinger, 2010; Gessler, 2017a; Pilz \& Fürstenau, 2019). The term cooperation between learning venues, introduced by the German Education Council in 1974 (GEC, 1974) to describe duality (company/school), has become established, although in 1964 already the German Committee on Education System defines duality on the basis of the learning places (German Committee on Education System, 1966). But often more than two learning venues are included (e.g. training workshop, virtual classroom) (e.g. Gessler, 2017a; Deissinger, 2010). However, cooperation between learning venues is only one element of duality inside the German dual system (e.g. Pilz \& Fürstenau 2019; Raggatt, 1988).

In the literature, especially with a focus on the transfer of a dual approach, the following criteria are discussed, which are important for the transfer of a dual system: The willingness of a company to provide training is crucial. Additionally, the existence of a legal framework, which allows the integration of such practices, on part of the host countries is relevant. Besides, not only scientific-based theoretical knowledge, but also experiential knowledge should be utilized. Cooperation between the state, the economy and the social partners is mentioned as a further criterion (Emmenegger et al., 2019). The focus should be on a holistic occupational profile, and vocational training should serve as a career-relevant measure (Fortwengel \& Jackson, 2016; Gonon, 2013; Lewis, 2007; Valiente \& Scandurra, 2017). Therefore, many actors are involved in vocational education (Billett \& Seddon, 2004) and the singular focus on the learning venues in this study is a strong reduction of the duality in the German dual system in order to gain initial insights.

In other countries, even without a widely implemented German dual system, cooperation between learning venues is also discussed (Markowitsch \& Wittig, 2020). For example, the polytechnics in India focus on a stronger link between theory and practice (Schneider \& Pilz, 2019). But it is not only system structures that involve a stronger link to practice, companies also want to implement dual practices. Often there are multinational companies, which, due to their specific organizational structure, initiate a form of duality locally, in order to be able to transfer their existing training programs and practices (e.g. Fortwengel \& Jackson, 2016; Pilz \& Li, 2014). For example, such cooperation is intended to train workers (Mitchell, 1998). Therefore, in the international context, cooperation between companies and vocational schools or universities and colleges, has already gained in importance and attracted scholarly attention (e.g. Graf \& Powell, 2017; Pilz, 2017; Valiente \& Scandurra, 2017). Based on the international context, this study expands the term of cooperation between learning venues to include academic courses, as well as vocational schools (see also section 3). 


\subsection{Necessary Principles for Successful Cooperation Between Learning Venues}

In this paper, cooperation between learning venues in Germany is critically examined. In particular, the lack of engagement on the part of schools and companies to promote cooperation between learning venues is criticized (Gessler, 2017a). Fürstenau et al. (2014) write: "The coordination on the local level between individual schools and companies is not regulated and often either happens by chance or is instigated for specific reasons, e.g. misbehavior of the apprentice in matters such as daily attendance" (p. 434).

Various principles, important in order for cooperation to be successful, are mentioned in the scientific discourse (e.g. Berliner, 1997; Kanter, 1994). As a result of the scientific discourse, a range of literature exists which "proceeds with steps to take to ensure 'successful' partnerships" (Davies \& Hentschke, 2006, p. 211). Kanter (1994) writes as follows: "Successful partnerships manage the relationship, not just the deal" (p. 96). In particular, successful partnerships were also given attention in vocational training research. One example is the study by Billett et al. (2007). Based on a study conducted in Australia, the researchers identified five principles that ensure the establishment and maintenance of cooperation within vocational education and training (Billett et al., 2007). Australia basically has a dual system, but it differs from the German dual system in several aspects such as different applied policies (Harris \& Deissinger, 2003). The first principle mentioned by the authors Billett et al. (2007) is: Building and maintaining shared purposes and goals. Accordingly, the interests of the actors involved must first be analyzed in order to be able to agree on a common strategy. The set objectives are derived from the identified local challenges. Through the identification, possible solutions are able to be developed. For example, actors enter into a cooperation because they are dissatisfied with the existing quality of the vocational school system. The second important principle is: Building and maintaining relations with partners. Within this principle, factors are mentioned that support the establishment and continuation of a relationship. According to this principle, for example, communication between the involved participants, mutual respect or the appreciation of (partial) success, are named. The third principle is: Building and maintaining capacities for partnership work. This includes infrastructure as well as resources that are relevant for cooperation. The defined goals can only be achieved if various resources are available. The researchers cite building and maintaining partnership governance and leadership as the fourth principle. Governance here means operating in partnership. Therefore, rules are necessary which define the respective roles. This definition should also prevent the pursuit of particular interests. Furthermore, actors must act sensitively, since the respective actions can also cause concern or even mistrust within the cooperation partners. The last principle named is: Building and maintaining trust and trustworthiness. The partners should be involved in confidence-building. The exchange of information can also have a positive effect in building trust. In addition, the development of a strategic plan, honesty and respect can help to build trust. 
Since the major focus here is on vocational training research, and our study is a pilot study, only three principles identified by Billett et al. (2007) are followed in our study: Building and maintaining shared purposes and goals, building and maintaining relations with partners, building and maintaining partnership governance and leadership. Since dual practices have not existed in Cancún for long, the other two principles are not considered in this study. For example, trust must be built over time (e.g. Dyer \& Chu, 2000), which in turn can have an impact on the provision of resources.

Even though the major focus here is on vocational training research, these three principles for successful cooperation are also cited in other disciplines. Economic geography can be mentioned as one example. While often, there only isolated actors in a region or country who try to change the institutional system of skill formation ('institutional entrepreneurs'), as in Vietnam (Wrana \& Revilla Diez, 2016), sometimes there is broader cooperation on vocational education and training, as for example in Mexico's manufacturing sector (Wiemann \& Fuchs, 2018). Economic geographers emphasize that space usually implies regional disparities, with growing regions as centers, and less prosperous regions that are in peripheral positions; thus, often a focus is on the particular conditions for regional growth and development. Examples are metropolitan areas and clusters. Porter (1998) inspired research on clusters in economic geography, as a possible target to study reduced costs that companies have when they have access to local skilled labor. As a result, enterprises and vocational training organizations can identify the training of skilled workers as a common objective, so that the region also benefits. The relationship between the partners also plays a role. For example, Bathelt et al. (2002) focus on local buzz, the diverse exchange of knowledge between actors on a local level, as fundamental for cooperation, where for example, rumors are exchanged. Reputation is a relevant resource for networking, and at the same time results from mutual interaction (Glückler, 2007; Glückler, 2014).

In addition to continuous ongoing cooperation, temporary personal face-to-face contacts are important (Ponds et al., 2009). All this contributes to successfully overcoming existing frictions (Bathelt et al., 2018). Accordingly, the various forms of communication must be taken into account for a successful cooperation. Governance is also discussed and recognized as relevant with reference to cooperation in vocational training (Glückler et al., 2011). Glückler et al. (2011) place the actors (e.g. companies and vocational schools) with their different roles and tasks, in the center of attention. This relates to broader fields of international research on how organizations can overcome institutional differences in space (Cantwell et al., 2010; Krzywdzinski \& Jo, 2020).

It is evident from these references that across disciplines, the definition of common goals, the formation of relationships and governance are considered important principles for successful cooperation. Although "guidelines for building better partnerships" (Callan \& 
Ashworth, 2004, p. 59) were provided in the scientific discourse of vocational education and training, the need for further research is mentioned (Callan \& Ashworth, 2004).

Consequently, the three principles of the study by Billett et al. (2007) serve as a starting point for our study of successful cooperation between learning venues in Cancún. The relevant research question in this paper is therefore: Are a common goal, communication between actors and joint action, equally important in cooperation between learning venues in Cancún?

\section{Methodology}

The research question was investigated by an interdisciplinary research team consisting of two senior and two junior researchers from the department of vocational education and of economic geography. For this study, a qualitative approach was chosen to gain explorative insights in order to approach the research subject. Besides, the qualitative approach is useful in order to distil and complete the important influencing variables in relation to answering the research objective. This contributes to results, in which relevant factors are not overlooked (Hollstein, 2011). Therefore, the study comprised qualitative interviews in Cancún in August 2019. The interviewees were selected on the basis of an intensive internet search, which took place in advance.

The interviews were conducted and interpreted as described in the following. Ten faceto-face and semi-structured interviews were conducted as bilateral or group interviews, with a total of 14 experts, such as five Human Resource managers from different hotels (two Mexican and three international hotels), three experts on the administrative level of two business-related authorities (municipal tourist office, tourism ministry), five persons of two educational organizations (headmasters and dual training coordinators of a university and a vocational school) and an expert of an employers' association, in order to gain a broad comprehensive picture of the players in the network of vocational training work in the hotel sector. The experts were selected for the semi-structured interviews because they have insider expertise and knowledge due to their work position (Bogner et al., 2009). A university is also involved in order to pursue this research question, because in Mexico not only companies, but especially universities seem to be very interested in the introduction of a dual system approach (Graf et al., 2014). Accordingly, various forms of combinations of locations of learning, including work-based learning activities (Evans et al., 2006) are considered here.

The questions for the semi-structured interviews were developed on the basis of theoretical literature of both disciplines, vocational education and economic geography, which is quoted in the second section. The focus of the questions was mainly on the macro- ("institutional structures and economic, social and political framework") and meso-level ("organisational and regulatory design of TVET") (Pilz \& Wiemann, 2021, p. 98). For example, the connection to the vocational school system or the training strategy of companies were in the 
foreground (Pilz \& Wiemann, 2021). The micro level was also considered in the interviews such as questions regarding training of learners in the hotels or the educational organizations, but the focus of this paper is on the other two levels. For this reason, questions were asked, for example, with whom cooperation are entered into and what the structure of the respective cooperation is. The interviews also included questions regarding the financing of vocational education. The interviews took place in Spanish and were subsequently fully transcribed. A total of about twelve hours could be evaluated; guided visits to the hotels or the educational organizations are not included in these hours. The evaluation of the interviews was carried out using qualitative content method in order to do justice to the specificity of the subject matter, the conceptual approach and the openness of the questions (Kuckartz, 2014). The transcripts allowed for case summaries that were closely aligned with the statements and did not show any evaluations. With the help of these summaries, categories and tables could be formed to achieve an analysis (Kuckartz, 2014).

Multi-star hotels in the Cancún hotel zone along the lagoon were included for the semistructured interviews. These hotels are primarily aimed at international guests, the majority of whom come from the USA (SEDETUR, 2019). The hotels in the city of Cancún (on the mainland beyond the lagoon), which are aimed primarily at business or individual travelers, were not included. The focus was on the 4- and 5-star hotels in the hotel zone, because these make up the majority of rooms available in the state in these two categories and therefore form the main agglomeration area (SEDETUR, 2018). The hotel companies located in the region are largely owned by US, Spanish, German and Mexican hotel chains. For this reason, the selection of the hotels was also based on the listed company headquarters. This procedure allows an overview of the cooperation between learning venues. The contact persons in the companies were Human Resource managers or the training officers. Since many actors are active in vocational education in Mexico (e.g. Wiemann \& Fuchs, 2018), business-related organizations, which promote vocational education (SEDETUR, n.d.; SEMS, n.d.), were also included in our study. In these organizations visited, interviews were conducted with people at the administrative level.

In order to better place the interview statements in the local context, an intensive web analysis was carried out, comprising an analysis of newspapers such as El Universal (a very popular Mexican newspaper) or databases from INEGI (National Institute of Statistics and Geography). Accordingly, various documents were reviewed for their content regarding vocational education and tourism in order to supplement and secure the knowledge. Both the interviews and the different documents complete the picture of vocational education in the tourism sector in Mexico, since this study uses different data sources (triangulation) (Bowen, 2009). 


\section{Presentation of the Findings for Cooperation Between Learning Venues in Cancún}

In order to answer our research question, the cooperation between learning venues in the hotel industry in Cancún is presented first. Since it is an exploratory study, the findings of the study will be presented before they are discussed in the following part (section 5) and there assigned to the three principles.

First, the decision regarding learning venues cooperation lies with the local hotels; they are not influenced by the headquarters. The learning venues cooperation exist between the hotels and the vocational school as well as between the hotels and the universities in order to provide dual approaches. Only if contracts persist between the hotels and the vocational training organizations, learners can gain practical learning in the hotels. On the one hand, the vocational school offers a Mexican dual system (MMFD). MMFD means that apprentices learn both in vocational schools and in companies (BIBB, 2015). Over half of the learning content are vocational subjects (Kis et al., 2009). In particular, companies and vocational schools play a significant role in training of learners. In the companies at least one person is responsible for the coordination of the learners and employees (called tutors), who should show the work to be done to the learners. Also, the vocational schools have on the one hand teachers who teach the contents and on the other hand a person who is in close contact with the companies (e.g. SEMS, n.d.). In Cancún, the vocational school, which can be assigned to the secondary school level, offers two training courses in the tourism sector, each lasting three years. During the first two years, apprentices are taught entirely at the vocational school, in the final year they spend four days a week in companies and one day at vocational school. The dual training is carried out for the apprentices in areas with rather low formal qualification requirements, such as assistant cook. At the end of the MMFD, the learners also receive their high school diploma in Cancún, through which they can enter university.

On the other hand, there are learning venues cooperation between the hotels and the universities. The local universities offer tourism related courses of study such as tourism management, which send interns for practical phases. The internships for students who also have English language skills, for example, take place at stations such as the reception, and other areas with direct customer contact. This allows a distinction to be made between vocational schools, providing apprentices for entry level occupations and universities providing interns for middle-level positions.

\subsection{Building and Maintaining Shared Purposes and Goals}

The interviewees mention principles that are important for cooperation between learning venues and which will be described in detail in the following. Firstly, it should be noted that 
the two actors (hotels and educational organizations (vocational school, university) have different interests and motives in relation to the vocational training, which is why it is important to set common goals. As already mentioned, there is a significant increase in the number of hotels in Cancún. Therefore, hotels are looking for skilled workers, which educational organizations are trying to prepare for their future professional life. Due to the shortage of skilled workers, both of the actors (hotels and educational organizations) not only have a common challenge but also a common objective, which is why they establish contact with each other. For example, hotel interviewees point out that practical training units prepare learners better for the future. According to one business-related authority the entire region becomes more competitive due to training measures. However, in spite of a common goal, own interests can also be pursued. The vocational training organizations have got their own motives such as the preference for larger local hotels:

"We are looking for large hotels that are recognized nationally and internationally. We want them because of their experience in the hotel business. So, we look for these hotels so that the learners have the opportunity to belong to a large, recognized hotel and that is what we look for too." (Educational Organization 1)

In addition to the educational organizations, the hotels also have their own motives. Some human resources managers emphasize their own, and the hotel's commitment to the training during the practical phases. Other interviewees express interest in the fact that the apprentices and interns represent a reserve pool for later recruitment needs. Still others openly admit that the apprentices and interns are cheap labor for the company. Almost none of the hotels pay a salary to the apprentices and students, apart from food, uniforms, and transport expenses. In contrast, students are obliged to pay their study fees.

Despite the different individual interests of the actors such as the hotels and the educational organizations, the vocational training for the students can only be implemented when the actors cooperate and pursue the common goal, as it is done in this example, by concluding contracts. The pursuit of a common idea is regarded as an essential principle, and the ideas of the two actors must therefore be in harmony.

\subsection{Building and Maintaining Relations With Partners}

Several interview partners point out the significance of communication between the cooperation partners. Face-to-face or other channels of communication can promote exchange between the hotels and educational organizations. The actors for example connect through messaging services such as Skype, telephone and regular meetings. Communication can be used as a tool in order to achieve a common goal and to sort out the contracts between the 
hotels and the educational organizations. Also, through communication positive results can be achieved for all concerned:

"That there is always communication, that we can always have a meeting [...]. As long as there is that part of communication, we can get better results from each member." (Hotel 1)

Through communication the actors can also agree on common objectives and all players can be informed of what is expected of them. For example, several hotels argue that they are reluctant to accept apprentices and interns for the practical phase in their companies for less than three months, because it would not be worthwhile. In their opinion, learners can gain more insight over a longer period of time.

\subsection{Building and Maintaining Partnership Governance and Leadership}

Not only the possibility of communication must be available, but also the areas of responsibility must be clearly established in order to be able to conclude contracts. Therefore, each cooperation partner should know what role they have in the cooperation. For example, two companies argue that learners in educational organizations need to be prepared for the business environment. In this context they should be taught the seriousness of practical learning, where the focus is once again shifting to communication in order to generate such coordination and avoid contract cancellations. Through the meetings, the vocational education organizations can ask what the hotels expect from the teachers. Only through communication can cooperation be successful, such as the training of a skilled worker. One interviewee describes this as follows:

"The communication between [Educational Organization] and hotel, working together to have a better product that, in this case, is the learner. That the learner goes well prepared to the hotel so that the hotels tell us: 'This is the perfect learner. This is what I need for my hotel'. So, I think that communication is the most important thing." (Educational Organization 1)

At the same time, this quote illustrates the responsibility of vocational training providers to prepare learners accordingly. This highlights the importance of the reports that provide information to the vocational education organizations. In these reports persons responsible for the learners in the hotels note the state of the learners as well as cases of inadequate student behavior. The training organizations receive the reports about once a month. This implies that a good preparation of the learners in the vocational education organizations is of a high priority in Cancún. As a result, the learners are no longer accepted for practical phases in their hotels, if the hotels are not satisfied with the "product": 
"Maybe these learners did not behave in the right way and then there is a problem. Because if a learner does not behave in the right way and provoke a situation inside the hotel that is not the right one, then we can cancel the training." (Hotel 2)

The hotels can terminate the contracts quite easily because they can train their employees independently. The hotels allow their employees a high degree of upward mobility through their own training offerings, which means that not every hotel relies on cooperation partners.

Nevertheless, a vocational training organization expresses the need for a division of responsibilities between the cooperation partners of the learning venues. According to this, the aspect of governance seems particularly important for vocational training organizations:

"The other scheme is operational work, collaboration: Neither can we leave all the responsibility to the hotel for the formation of the student, nor should the hotel leave it to us. It is a matter of collaboration and balance." (Educational Organization 2)

Besides, the interviews also show that the contracts between the hotels and the vocational training organizations mainly include the legal aspects, for example, what happens when a learner has an accident at work or that the learners continue to have a pupil or student status. The contracts convey less of the contents. In the hotels, the department heads of the respective stations are responsible for the learners. Therefore, the department heads decide which practical skills are taught to the learners.

\section{Discussion of the Findings}

In the following, the findings from the previous section will be assigned to the three principles of Billett et al. (2007), which are in focus. The findings are thus structured according to the three selected principles. As the following shows the findings are related to the theoretical framework presented in chapter two.

\subsection{Building and Maintaining Shared Purposes and Goals}

In order to present the aspect of common objectives precisely, a separation of two different perspectives concerning the actors is crucial. On the one hand the focus can only be on the same group or type of actors (different hotels), and on the other hand between the different types of actors (educational organizations versus hotels). This distinction highlights differences which have an influence on the setting of common objectives.

If the hotels in Cancún alone are considered, it can be concluded that even though the great demand for skilled labor in the tourism industry is obvious, the hotels do not enter into agreements among themselves to train skilled workers jointly. Due to the strong local 
competition, the hotels are afraid that their staff will move away. This is also illustrated by the following quotation:

"As here is a lot of supply, the workers suddenly say: "They will pay me 300 pesos more or 200 pesos more over there. [...] I'm going because they're going to pay me more there'." (Hotel 2)

Consequently, the liberal labor market with little regulation, a high rate of labor-turnover, and the risk of poaching (Mohrenweiser et al., 2013; Muehlemann \& Wolter, 2011) not only has an influence on the setting of common goals. Due to the high level of competition, hotels do not seem to pursue common goals among themselves. This indicates that the hotels do not cooperate with each other in this respect.

However, if the aspect of common goals between various groups of actors is examined, a different result emerges. The individual hotels and the vocational training organizations both have an interest in skilled workers, so that the common goal is found. This goal in particular may become more important in the future, as more hotel zones are being built around the city, which means that more skilled workers are needed. Only when the potential cooperation partners realize that they will benefit from more intensive cooperation, more specific measures can be identified and implemented. There are a lot of hotels entering into partnerships with vocational training organizations in order to train skilled workers together. Therefore, if the different groups of actors are at the center, the results of Billett et al. (2007) can be confirmed. The different interests can be pursued together because they harmonize with the common goal. Thus, hotels get skilled workers and vocational training organizations have got more learners, who in turn pay tuition fees.

In addition, the community can also be mentioned as another actor that aims to promote regional development. Cooperation between learning venues can enable this goal. Finally, the entire region can benefit from the common goals of different players (Porter, 1998). Thus, the definition of common goals between the actors is crucial. The insight of the involvement of different actors should be understood in the further course of the work in relation to common goals.

\subsection{Building and Maintaining Relations With Partners}

A difference to the study by Billett et al. (2007) can be seen with regard to the principle of "building and maintaining relations with partners", because it seems that communication in particular, stands out as an important principle. Common goals for the different actors can only be set through communication. Vocational training organizations in particular require the exchange of information with the hotels, as this enables them to prepare learners accordingly. Consequently, vocational training organizations especially are dependent on knowing what the hotels expect from them. Discussions can set out the expectations. Therefore, our results 
suggest that Callan and Ashworth's (2004) statement that communication between actors is important is confirmed. Likewise, the necessity of local buzz is evident (Bathelt et al., 2002).

In Cancún, vocational training organizations seem to depend more on the contracts with the hotels, because only in this way are practical phases possible. For this reason, perceived challenges must also be communicated so that both actors can act. Billett et al. (2007) cite mutual respect as one key to fostering the relationship. In Cancún, this respect is only perceptible to a certain extent, since, for example, legal contracts can be concluded quickly, but at the same time can be revoked easily. Likewise, the appreciation of partial successes is not mentioned. Therefore, all forms of communication seem to gain in importance.

Tynjälä (2008) writes with regard to relationship between schools and companies: "It is important that school-based and work-based learning enter into a closer relationship" (p. 150). This is possible if there is a stronger link between companies and vocational training organizations. Accordingly, communication may be essential if relationships between partners are to be strengthened (Kanter, 1994). The findings therefore indicate that the relations between cooperation partners are probably not very close. It should be examined whether more commitment from the actors is required (Gessler, 2017a) or how the relationship can be further strengthened.

\subsection{Building and Maintaining Partnership Governance and Leadership}

With regard to the principle of "building and maintaining partnership governance and leadership", further conclusions become evident if we focus on the case of Cancún. First of all, it becomes obvious that there is no partnership-based action between the hotels and the educational organizations. The hotels are in a dominant position because there are about 1,000 hotels on site, which are in competition with each other. Therefore, there is cost pressure on the part of the hotels in order to remain competitive. Hence, they can also quickly terminate contracts with vocational training organizations, if, for example, the learners do not behave according to expectations. The contracts indemnify the hotel if the students are involved in an accident at work. In addition, the hotels ensure that the learners are not employees and that they maintain their learner status. Thus, the hotels do not have to pay the learners a salary. There is also no clear outline of what the learners should learn where. From these remarks, it is evident that the cooperation between learning venues in Cancún is not a matter of partnership; because hotels can train their own employees completely, and an employee can advance from dishwasher to director, it is obvious that the vocational training organizations are dependent on the hotels whereas hotels are not dependent on the training organizations to the same extent. The responsibility is therefore not shared equally.

Since the dual training system is still quite young, and has only been implemented in recent years, the understanding of the other roles may need to be sharpened. Accordingly, 
a common consensus would have to be developed in the future to define the various roles. Furthermore, it is not quite clear how the goal of training skilled workers by the different actors is to be achieved. Possibly this is a further point of view, which must be considered in more detail in the future. However, studies already show that even in Germany equal partnerships with regard to cooperation between learning venues do not exist to any large extent (Fürstenau et al., 2014; Gessler, 2017a); thus, this aspect is not unique to Cancún.

Contrary to an earlier study (Baum, 2002), the different actors in Cancún are not dependent on each other. Rather, our data show that the willingness of companies is particularly important in order to enter into cooperation. If more companies are motivated, for example by vocational training organizations taking greater account of the needs of companies (Billett, 2000), then the aspect of governance can become more relevant. For this reason, vocational training organizations have a primary responsibility towards learners in Cancún.

In summary, it can be concluded that the most important principles for successful cooperation between learning venues are that the different actors have common goals and that there should be good communication between the cooperation partners. It is also apparent that the governance aspect between hotels and educational organizations is not yet strongly developed in Cancún. In addition, however, it also becomes evident that hotels are reluctant to set common goals with other hotels because of the fear of losing employees.

It can be concluded that this study provides some indications not only for Cancún, but for tourism in Mexico, and, for example, for further regions in Latin America. But the transfer of findings can only be done very cautiously, as country and local specifics have to be taken into account, which, however, cannot be discussed here. In general, the findings show and literature underlines that cooperation between learning venues can contribute to improve local skill formation systems (Mitchell, 1998). Recently, companies have successfully started cooperation between learning venues with both universities and vocational schools (e.g. Graf \& Powell, 2017; Pilz, 2017; Valiente \& Scandurra, 2017). But efforts are always needed to strengthen collaborations (Thelen, 2004). In particular, maintaining relationship as well as maintaining partnership governance are central if collaborations are to be successful in the future. For this reason, actors must rely on a variety of mechanisms to achieve common goals.

\section{Conclusion}

The results indicate that the cooperation of the different actors, which the paper considered very important at the beginning on the basis of the previous research findings, is also of central importance in the empirical case. In particular, the findings show that certain principles are needed. The definition of common goals by the different players, as well as the communication between the hotels and the vocational training organizations, are both necessary 
for successful cooperation between learning venues. Furthermore, it seems that there are no complex governance structures. This is particularly due to the fact that hotels are in a stronger position, and dominate the vocational training organizations. It may be important to point out that the state has little influence because the government sets only basic standards. In particular, the state seems to have little influence on the curricula in detail or the contractual arrangements for learners, so that the hotels have a powerful role. Consequently, the constellation of actors must be considered in order to obtain more information about cooperation in Cancún (Emmenegger et al., 2019).

As a result of our study in Cancún, we assume that cooperation between learning venues is advantageous not only for the entire region, but also for the hotels, vocational schools and universities. Hotels can select their future staff from the pool of learners, and vocational education organizations can offer these training courses. The interviewees state that learners benefit from such cooperation because they gain practical experience. Nevertheless, we do not exclude on the basis of these results, that other successful training arrangements may also exist (e.g. Gessler, 2017b; Peters, 2019).

Specifics in other regions and industries may influence the actions of actors, so different principles may be needed for successful collaborations. Accordingly, external factors must be considered. External factors are country-specific contextual influences which can have an impact on the training measures of companies. For example, external factors such as the local labor market or connectivity to the vocational school system must also be considered (Vogelsang \& Pilz, 2021) in order to determine the required principles. As a consequence, it is important to identify the necessary principles before attempting to bring about a cooperation in order to make it successful. Amery (2000) describes this as follows: "Organizations might wish to consider ways to foster partnership working, such as joint training initiatives with partner organizations or professional groups [...]. It will be important to identify those factors that enable sustained commitment to working together" (p. 30). It is therefore evident that each partnership needs different principles in order to be sustained, but which must be agreed upon. By identifying the necessary principles, partnerships can exist in the long term, because the actors are satisfied with the cooperation (Anderson \& Narus, 1990). Thus, the cancellation of cooperations can be prevented.

However, there are limitations in our study, as only ten expert interviews were conducted, in one city. It should be pointed out that Cancún is a special tourist region, so the statements should be considered with caution. Therefore, further research is needed to investigate whether similar results would be achieved in other regions. Similarly, a long-term study can identify whether, for example, other necessary principles are relevant. Further research is also necessary with a view to a broader network. This raises the question of whether governance in a larger network should be given greater importance. 


\section{Acknowledgement}

The article is based on the research project "DualReg: Locally rooted - worldwide linked up: Mexico - Success conditions for transfer of vocational education and dual practices". This project was funded by the Federal Ministry of Education and Research under the funding code $01 \mathrm{BF} 18002 \mathrm{~A}$. The content of this publication is the responsibility of the authors.

\section{References}

Amery, J. (2000). Interprofessional working in health action zones: How can this be fostered and sustained? Journal of Interprofessional Care, 14(1), 27-30. https://doi.org/10.1080/jic.14.1.27.30

Anderson, J. C., \& Narus, J. A. (1990). A model of distributor firm and manufacturer firm working partnerships. Journal of Marketing, 54(1), 42-5. https://doi.org/10.2307/1252172

Augustyn, M. M., \& Knowles, T. (2000). Performance of tourism partnerships: A focus on York. Tourism Management, 21(4), 341-351. https://doi.org/10.1016/S0261-5177(99)00068-0

Barabasch, A., \& Heller, N. (2020). The Swiss PET system and similar programs in Germany and Austria. In M. Pilz \& J. Li (Eds.), Comparative vocational education research enduring challenges and new ways forward (pp. 97-112). Springer VS. https://doi.org/10.1007/978-3-658-29924-8_6

Bathelt, H., Malmberg, A., \& Maskell, P. (2002). Clusters and knowledge: Local buzz, global pipelines and the process of knowledge creation. Progress in Human Geography, 28(1), 31-56. https://doi. org/10.1191/0309132504ph469oa

Bathelt, H., Cantwell, J. A., \& Mudambi, R. (2018). Overcoming frictions in transnational knowledge flows: Challenges of connecting, sense-making and integrating. Journal of Economic Geography, 18(5), 1001-1022. https://doi.org/10.1093/jeg/lby047

Baum, T. (2002). Skills and training for the hospitality sector: A review of issues. Journal of Vocational Education and Training, 54(3), 343-354. https://doi.org/10.1080/13636820200200204

Berliner, B. (1997). What it takes to work together: The promise of educational partnerships. Knowledge Brief. No. 14. WestEd.

Bianet Castellanos, M. (2010). Cancún and the campo. Indigenous migration and tourism development in the Yucatán Peninsula. In D. Berger \& A. G. Wood (Eds.), Holiday in Mexico. Critical reflections on tourism and tourist encounters (pp. 241-284). Duke University Press. https://doi. org/10.2307/j.ctv11cw4hv.13

Billett, S. (2000). Defining the demand side of VET: Industry, enterprises, individuals and regions. Journal of Vocational Education and Training, 50(1), 5-30. https://doi.org/10.1080/13636820000200104

Billett, S., \& Seddon, T. (2004). Building community through social partnerships around vocational education and training. Journal of Vocational Education and Training, 56(1), 51-68. https://doi. org/10.1080/13636820400200245

Billett, S., Ovens, C., Clemans, A., \& Seddon, T. (2007). Collaborative working and contested practices: Forming, developing and sustaining social partnerships in education. Journal of Education Policy, 22(6), 637-656. https://doi.org/10.1080/02680930701625288

Bogner, A., Littig, B., \& Menz, W. (2009). Introduction: Expert interviews - an introduction to a new methodological debate. In A. Bogner, B. Littig \& W. Menz (Eds.), Interviewing experts (pp. 1-13). Palgrave Macmillan UK. https://doi.org/10.1057/9780230244276_1 
Bowen, G. A. (2009). Document analysis as a qualitative research method. Qualitative Research Journal, 9(2), 27-40. https://doi.org/10.3316/QRJ0902027

Brenner, L., \& Aguilar, A. G. (2002). Luxury tourism and regional economic development in Mexico. The Professional Geographer, 54(4), 500-520. https://doi.org/10.1111/0033-0124.00346

Brown, P., Green, A., \& Lauder, H. (2001). High skills. Globalization, competitiveness and skill formation. Oxford University Press. https://doi.org/10.1093/acprof:oso/9780199244188.001.0001

Budría, S., \& Telhado-Pereira, P. (2009). The contribution of vocational training to employment, jobrelated skills and productivity: Evidence from Madeira. International Journal of Training and Development, 13(1), 53-72.

Callan, V., \& Ashworth, P. (2004). Working together. Industry and VET provider training partnerships. National Centre for Vocational Education Research.

Cantwell, J., Dunning, J. H., \& Lundan, S. M. (2010). An evolutionary approach to understanding international business activity: The co-evolution of MNEs and the institutional environment. Journal of International Business Studies, 41, 567-586. https://doi.org/10.1057/jibs.2009.95

Carte, L., McWatters, M., Daley, E., \& Torres, R. (2010). Experiencing agricultural failure: Internal migration, tourism and local perceptions of regional change in the Yucatan. Geoforum, 41(5), 700710. https://doi.org/10.1016/j.geoforum.2010.03.002

Davies, B., \& Hentschke, G. (2006). Public-private partnerships in education: Insights from the field. School Leadership and Management, 26(3), 205-226. https://doi.org/10.1080/13632430600736977

Deissinger, T. (2010). Dual system. In P. Peterson, E. Baker \& B. McGaw (Eds.), International encyclopedia of education (3rd ed., pp. 448-454). Elsevier.

Dyer, J. H., \& Chu, W. (2000). The determinants of trust in supplier-automaker relationships in the U.S., Japan, and Korea. Journal of International Business Studies, 31(2), 259-285. https://doi. org/10.1057/palgrave.jibs.8490905

Emmenegger, P., Graf, L., \& Trampusch, C. (2019). The governance of decentralised cooperation in collective training systems: A review and conceptualisation. Journal of Vocational Education \& Training, 71(1), 21-45. https://doi.org/10.1080/13636820.2018.1498906

Evans, K., Hodkinson, P., Rainbird, H., \& Unwin, L. (2006). Improving workplace learning. Routledge.

Federal Institute for Vocational Education and Training. (BIBB) (n.d.). Germany supports the continued development of dual education and training in Mexico. BIBB.

Federal Institute for Vocational Education and Training. (BIBB) (2015). New alliance in German-Mexican vocational education and training cooperation. BIBB.

Federal Ministry of Education and Research. (BMBF) (2013). Strategiepapier der Bundesregierung: Berufsbildungszusammenarbeit aus einer Hand vom 5. Juli 2013.

Fortwengel, J., \& Jackson, G. (2016). Legitimizing the apprenticeship practice in a distant environment: Institutional entrepreneurship through inter-organizational networks. Journal of World Business, 51(6), 895-909. https://doi.org/10.1016/j.jwb.2016.05.002

Fürstenau, B., Pilz, M., \& Gonon, P. (2014). The dual system of vocational education and training in Germany - what can be learnt about education for (other) professions. In S. Billett, C. Harteis \& H. Gruber (Eds.), International handbook of research in professional and practice-based learning (pp. 427-460). Springer. https://doi.org/10.1007/978-94-017-8902-8_16

German Committee on Education System. (1966). Empfehlungen und Gutachten des Deutschen Ausschusses für das Erziehungs- und Bildungswesen 1953-1965. Gesamtausgabe. Ernst Klett. 
German Education Council. (GEC) (1974). Gutachten und Studien der Bildungskommission. Die Bedeutung verschiedener Lernorte in der beruflichen Bildung. Ernst Klett.

German-Mexican Chamber of Industry and Commerce. (CAMEXA) (n.d.). El modelo Mexicano de la formación dual. https://mexiko.ahk.de/es/dual/formacion-dual-mexicana

Gessler, M. (2017a). The lack of collaboration between companies and schools in the German dual apprenticeship system: Historical background and recent data. International Journal for Research in Vocational Education and Training, 4(2), 164-195. https://doi.org/10.13152/IJRVET.4.2.4

Gessler, M. (2017b). Educational transfer as transformation: A case study about the emergence and implementation of dual apprenticeship structures in a German automotive transplant in the United States. Vocations and Learning, 10(1), 71-99. https://doi.org/10.1007/s12186-016-9161-8

Glückler, J. (2007). Geography of reputation: The city as the locus of business opportunity. Regional Studies, 41(7), 949-961. https://doi.org/10.1080/00343400601145194

Glückler, J. (2014). How controversial innovation succeeds in the periphery? A network perspective of BASF Argentina. Journal of Economic Geography, 14(5), 903-927. https://doi.org/10.1093/jeg/ lbu016

Glückler, J., Németh, S., \& Melot de Beauregard, P. (2011). Netzwerke: Rechtsformen und Folgen für die Zusammenarbeit von Unternehmen. Der Betrieb, 64(48), 2701-2709.

Gonon, P. (2013). What makes the dual system to a dual system? A new attempt to define VET through a governance approach. bwp@, 25. http://www.bwpat.de/ausgabe25/gonon_bwpat25.pdf

Graf, L., Powell, J. J. W., Fortwengel, J., \& Bernhard, N. (2014). Dual study programmes in global context: Internationalisation in Germany and transfer to Brazil, France, Qatar, Mexico and the US. DAAD. Ditges print+more gmbh.

Graf, L., \& Powell, J. J. W. (2017). How employer interests and investments shape advanced skill formation. Cambridge University Press, 50(2), 418-422. https://doi.org/10.1017/S1049096516002936

Harris, R., \& Deissinger, T. (2003). Learning cultures for apprenticeships: A comparison of Germany and Australia. Searle, J. et al. (Eds.), Enriching learning cultures: Proceedings of the 11th annual international conference on post-compulsory education and training, 2, 23-33. Australian Academic Press.

Hollstein, B. (2011). Qualitative approaches. In J. Scott \& P. J. Carrington (Eds.), The sage handbook of social network analysis (pp. 404-416). SAGE Publications Ltd.

International Labour Organization. (ILO) (2011). A skilled workforce for strong, sustainable and balanced growth. A G20 strategy. International Labour Office.

Kanter, R. M. (1994). Collaborative advantage: The art of alliances. Harvard Business Review, 72(4), 96-108.

Kis, V., Hoeckel, K., \& Santiago, P. (2009). OECD reviews of vocational education and training: Learning for jobs review of Mexico 2009. OECD Publishing. https://doi.org/10.1787/20777736

Krzywdzinski, M., \& Jo, H. J. (2020). Skill formation, automation and governance: Comparing German and Korean automotive manufacturers in central-eastern Europe. Critical Perspectives on International Business.

Kuckartz, U. (2014). Qualitative text analysis. A guide to methods, practice \& using software. SAGE Publications Ltd. https://dx.doi.org/10.4135/9781446288719

Lassnigg, L. (2017). Apprenticeship policies coping with the crisis: A comparison of Austria with Germany and Switzerland. In M. Pilz (Ed.), Technical and vocational education and training: Issues, concerns and prospects (pp. 127-148). Springer. https://doi.org/10.1007/978-3-319-47856-2_7 
Lewis, T. (2007). The problem of cultural fit - what can we learn from borrowing the German dual system? Compare: A Journal of Comparative and International Education, 37(4), 463-477. https:// doi.org/10.1080/03057920701366408

López, A. M. (2020a). Tourism in Latin America - statistics \& facts. STATISTA. https://www.statista. com/topics/2068/travel-and-tourism-industry-in-latin-america/

López, A. M. (2020b). International tourism revenue in Latin America in 2017 and 2018, by subregion. STATISTA. https://www.statista.com/statistics/305468/international-tourism-receipts-of-latinamerica-by-region/

Markowitsch, J., \& Wittig, W. (2020). Understanding differences between apprenticeship programmes in Europe: Towards a new conceptual framework for the changing notion of apprenticeship. Journal of Vocational Education \& Training. https://doi.org/10.1080/13636820.2020.1796766

Mitchell, A. (1998). Strategic training partnerships between the State and enterprises. International Labour Office.

Mohrenweiser, J., Zwick, T., \& Backes-Gellner, U. (2013). Discussion paper no. 13-037. Poaching and firm-sponsored training: First clean evidence. Centre for European economic research.

Muehlemann, S., \& Wolter, S. (2011). Firm-sponsored training and poaching externalities in regional labor markets. Regional Science and Urban Economics, 41(6), 560-570. https://doi.org/10.1016/j. regsciurbeco.2011.04.003

Organisation for Economic Co-operation and Development. (OECD) (2017). Tourism policy review of Mexico, OECD studies on tourism. OECD Publishing. http://dx.doi.org/10.1787/9789264266575en [21.03.2020]

Organisation for Economic Co-operation and Development. (OECD) (2018). OECD reviews of vocational education and training. Seven questions about apprenticeships. Answers from international experience. OECD Publishing. https://www.oecd-ilibrary.org/docserver/9789264306486-en. pdf ?expires $=1604925683 \&$ id $=$ id\&accname $=$ ocid41021573\&checksum $=$ B1A09A6FDA7DCCE9F DBFF3C30C47C0CB

Peters, S. (2019). Bildungstransfer im Unternehmenskontext. Springer VS. https://doi.org/10.1007/9783-658-25819-1

Pilz, M. (2016). Typologies in comparative vocational education: Existing models and a new approach. Vocations and Learning, 9(3), 295-314. https://doi.org/10.1007/s12186-016-9154-7

Pilz, M. (2017). Policy borrowing in vocational education and training (VET) - VET system typologies and the "6 p strategy" for transfer analysis. In M. Pilz (Ed.), Vocational education and training in times of economic crisis. Lessons from around the world (pp. 473-490). Springer International. https://doi.org/10.1007/978-3-319-47856-2_26

Pilz, M., \& Fürstenau, B. (2019). Duality and learning fields in vocational education and training: Pedagogy, curriculum, and assessment. In Guile, D. \& Unwin, L. (Eds.), The wiley handbook of vocational education and training (pp. 311-327). Wiley. https://doi.org/10.1002/9781119098713.ch16

Pilz, M., \& Li, J. (2014). Tracing teutonic footprints in VET around the world? The skills development strategies of German companies in the USA, China and India. European Journal of Training and Development, 38(8), 745-763.

Pilz, M., \& Wiemann, K. (2021). Does dual training make the world go round? Training models in German companies in China, India and Mexico. Vocations and Learning, 14(1), 95-114. https:// doi.org/10.1007/s12186-020-09255-Z 
Ponds, R., van Oort, F., \& Frenken, K. (2009). Innovation, spillovers and university-industry collaboration: An extended knowledge production function approach. Journal of Economic Geography, 10(2), 231-255. https://doi.org/10.1093/jeg/lbp036

Porter, M. (1998). Cluster and competition: New agendas for companies, government and institutions. In M. Porter (Ed.), On competition (pp. 197-299). Harvard Business School Press.

Raggatt, P. (1988). Quality control in the dual system of west Germany, Oxford Review of Education, 14(2), 163-185.

Reyes Miranda, F., \& Cazal Ferreira, A. (2009). Migrantes reciente y nuevas ciudades. El caso de cancún, Mexico. XXVII Congreso de la asociación Latinoamericana de sociología. VIII Jornadas de sociología de la universidad de Buenos Aires. Asociación Latinoamericana de sociología. http://cdsa. aacademica.org/000-062/751.pdf/

Schneider, S., \& Pilz, M. (2019). The function and institutional embeddedness of polytechnics in the Indian education system. International Journal for Research in Vocational Education and Training, 6(3), 284-308. https://doi.org/10.13152/IJRVET.6.3.5

Secretaría de Educación Media Superior. (SEMS) (n.d.). Metodología y criterios para la implementación de los programas de formación dual. http://www.sems.gob.mx/work/models/sems/Resource/12345/2/images/Metodologia-y-criterios-para-implementacion.pdf

Secretaría de Turismo. (SEDETUR) (2018). Actividad Hotelera en México por categoría (anual). https://www.datatur.sectur.gob.mx/ITxEF/ITxEF_QROO.aspx

Secretaría de Turismo. (SEDETUR) (n.d.). Misión y visión. https://qroo.gob.mx/sedetur/mision-yvision/

Secretaría de Turismo. (SEDETUR) (2019). ¿Cómo vamos en turismo de Quintana Roo? Período de enero-septiembre 2019 vs 2018. http://sedeturqroo.gob.mx/ARCHIVOS/COMO_VAMOS_ENERO_SEPTIEMBRE_2019.pdf

Secretaría de Turismo. (SEDETUR), \& Instituto Nacional de Estadística y Geografía (INEGI) (2020). Empleo turístico. https://www.datatur.sectur.gob.mx/SitePages/ResultadosITET.aspx

Smith, E. (2019). Apprenticeships and 'future work': Are we ready? International Journal of Training and Development, 23(1), 69-88. https://doi.org/10.1111/ijtd.12145

Statista. (2018). Number of international visitors in the most popular Latin American city destinations in 2018. https://www.statista.com/statistics/310542/overnight-visitors-to-top-latin-american-citydestinations/

Statista. (2020). Number of international tourists in Cancun, Mexico from 2016 to 2025. https://www. statista.com/statistics/805974/number-international-tourists-cancun/

Thelen, K. (2004). How institutions evolve. Cambridge University Press. https://doi.org/10.1017/ CBO9780511790997

Torres, R. M., \& Momsen, J. D. (2005a). Gringolandia: The construction of a new tourist space in Mexico. Annals of the Association of American Geographers, 95(2), 314-335. https://doi.org/10.1111/ j.1467-8306.2005.00462.x

Torres, R. M., \& Momsen, J. D. (2005b). Planned tourism development in Quintana Roo, Mexico: Engine for regional development or prescription for inequitable growth? Current Issues in Tourism, 8(4), 259-285. https://doi.org/10.1080/13683500508668218

Tynjälä, P. (2008). Perspectives into learning at the workplace. Educational Research Review, 3(2), 130154. https://doi.org/10.1016/j.edurev.2007.12.001 
Valiente, O., \& Scandurra, R. (2017). Challenges to the implementation of dual apprenticeships in OECD Countries: A literature review. In M. Pilz (Ed.), Vocational education and training in times of economic crisis. Lessons from around the world (pp. 41-57). Springer International. https://doi. org/10.1007/978-3-319-47856-2_3

Vogelsang, B., \& Pilz, M. (2021). Conditional factors for training activities in Chinese, Indian and Mexican subsidiaries of German companies. European Journal of Training and Development, 45(4/5), 419-435.

Wiemann, J., \& Fuchs, M. (2018). The export of Germany's 'secret of success' dual technical VET: MNC and multiscalar stakeholders changing the skill formation system in Mexico. Cambridge Journal of Regions, Economy and Society, 11(2), 373-386. https://doi.org/10.1093/cjres/rsy008

Wrana, J., \& Revilla Diez, J. (2016). Can multinational enterprises introduce new institutions to host countries? An explorative study about MNEs' training programs with educational institutes and their potential influence on Vietnam's vocational education sector. Geographische Zeitschrift, 104(3), 158-182.

\section{Biographical Notes}

Beke Vogelsang is a research assistant and $\mathrm{PhD}$ student at the Chair of Economics and Business Education at the University of Cologne in Germany. Her research interest includes international research in vocational education. One research focus is on cooperation between different actors.

Natascha Röhrer is a research assistant and $\mathrm{PhD}$ student at the Department of Economic and Social Geography at the University of Cologne in Germany. Her research interests are regional innovation systems with focus on networks and cooperation.

Prof. Dr Martina Fuchs was appointed professor at the University of Lueneburg in 2002. Since 2004, she has been professor for economic and social geography at the University of Cologne. Her research topics are globalization, regional learning, skills and the geography of labour.

Prof. Dr Matthias Pilz is Professor of Economics and Business Education at the University of Cologne in Germany and Director of the German Research Center for Comparative Vocational Education and Training (G.R.E.A.T.). His research interests are in international comparative research in VET, transitions from education to employment, and teaching and learning. 